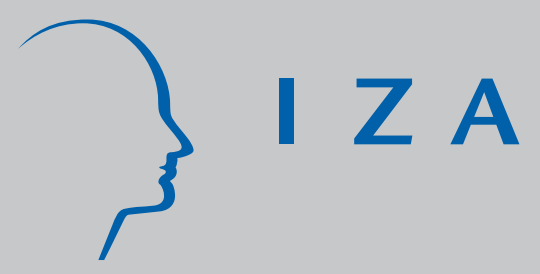

IZADP No. 3663

Reassessing the Wage Penalty for Temps in Germany

Elke J. J ahn

August 2008 


\title{
Reassessing the Wage Penalty for Temps in Germany
}

\author{
Elke J. Jahn \\ University of Arrhus, \\ $I A B$ and IZA
}

\section{Discussion Paper No. 3663 \\ August 2008}

\author{
IZA \\ P.O. Box 7240 \\ 53072 Bonn \\ Germany \\ Phone: +49-228-3894-0 \\ Fax: +49-228-3894-180 \\ E-mail: iza@iza.org
}

\begin{abstract}
Any opinions expressed here are those of the author(s) and not those of IZA. Research published in this series may include views on policy, but the institute itself takes no institutional policy positions.

The Institute for the Study of Labor (IZA) in Bonn is a local and virtual international research center and a place of communication between science, politics and business. IZA is an independent nonprofit organization supported by Deutsche Post World Net. The center is associated with the University of Bonn and offers a stimulating research environment through its international network, workshops and conferences, data service, project support, research visits and doctoral program. IZA engages in (i) original and internationally competitive research in all fields of labor economics, (ii) development of policy concepts, and (iii) dissemination of research results and concepts to the interested public.
\end{abstract}

IZA Discussion Papers often represent preliminary work and are circulated to encourage discussion. Citation of such a paper should account for its provisional character. A revised version may be available directly from the author. 
IZA Discussion Paper No. 3663

August 2008

\section{ABSTRACT}

\section{Reassessing the Wage Penalty for Temps in Germany}

As a consequence of the rapid growth of temporary agency employment in Germany, the debate on the poor working conditions of temps, specifically their remuneration, has intensified recently. Using administrative data, the paper shows that the wage gap for German temp workers is rather large and varies between occupation and region. But temps already suffer from a marked wage decline before entering the temporary help sector. Nevertheless, temporary agency employment does not leave a long lasting scar. Two years after leaving the sector, temps no longer suffer from a wage penalty. A recent change in the law set a high incentive for temporary help agencies to pay their workers according to a sectoral collective agreement. Surprisingly, the unionization of the sector could not bring the widening wage gap to a halt.

JEL Classification: J30, J31, J42

Keywords: temporary agency employment, wage differential, earnings, Germany, reform

Corresponding author:

Elke J. Jahn

Department of Economics

Århus School of Business

University of Aarhus

Prismet, Silkeborgvej 2

DK-8000 Aarhus C

Denmark

E-mail: elja@asb.dk 


\section{Introduction}

As part of the general movement towards increased flexibility in employment, temporary agency employment nearly doubled in most European countries in the past decade. In the European Union, the temporary help sector employed 3.3 million agency workers or 1.8 percent of the EU working population in 2006 (CIETT 2007). Generally, temporary agency employment is characterized by a tripartite relationship whereby a temp worker is employed by a temp agency, which then hires the worker out under a commercial contract to perform a work assignment at a user firm. The agency is considered to be the employer, determining issues such as wages and terms of employment. The user company has the right to assign tasks to the temp and to supervise his or her work.

The rapid growth of this employment form has raised concerns about working conditions and the quality of jobs generated in this industry, predominantly about the level of wages (e.g. Jørgensen 2007). Beside national interest groups and unions, the European Commission sees the working conditions and remuneration of temps as an important area to regulate. In December 2007, a long-lasting discussion on a draft directive on temporary agency workers was revived. The central aim of the proponents is to prevent discrimination against agency temps by guaranteeing equal treatment for temps in terms of pay and working conditions as workers employed by the user company to do the same job (Eurofound 2007).

Somewhat paradoxically, this has occurred in the absence of any sound empirical evidence. Empirical research estimating the wage gap between temporary agency workers and regularly employed workers is still in its infancy. The few empirical studies summarized in Section 2 indicate that most temp workers must indeed accept lower wages compared to workers hired directly by non-temp firms. There are three reasons why the available evidence should be treated with caution: 
First, due to the lack of high quality panel data, which often does not allow controlling for workers' characteristics and previous employment history, empirical evidence is still preliminary. Second, there is some indication that workers already suffer from a wage decline before entering into temporary agency employment. As a consequence, studies that fail to take preearnings into account will overestimate the wage differentials. Third, the market for temp workers seems to be highly segmented. Proponents of the "knowledge economy" thesis have pointed to the growing attractiveness of agencies for highly skilled workers, specifically for engineers and workers with technical occupations. Whereas the labor market segment for highly skilled workers is tight, there is an excess supply of workers in the segment for low skilled jobs. In the tight segment of the labor market, agencies are often left with highly motivated flexible workers who prefer to work flexibly or professionals who can earn more by working on a flexible basis. These two groups might therefore have the power to bargain higher wages than the regular labor market provides them with (Forde and Slater 2005, Houseman et al. 2003). At the same time temp workers in the labor market segment for lowskilled workers may be prepared to buy themselves into a job by accepting lower wages.

Germany is an interesting case to analyze: First, Germany’s temporary help sector experienced considerable growth during the past decade. The share of temporary agency workers increased from 0.8 percent in 1997 to 2.7 percent in 2007, employing 730 thousand workers in 2007. Second, there were very few sectoral collective agreements in the temporary help sector prior to 2003. This has been seen as one reason why the wage gap between temps and non-temps in Germany is high. As a consequence of a fundamental reform of the law regulating the temporary help sector, nearly all temporary help agencies signed sectoral collective agreements in 2003. If, as has often been suspected (e.g. Segal and Sullivan 1998), the lack of bargaining power of the temps is the main reason for the wage gap, then the temp wage penalty should have disappeared or been at least reduced after the reform. 
The paper gives some preliminary answers to the following questions: First, how did wages of temps evolve over time? Second, are wage differentials a result of worker characteristics or are they occupation-specific? Third, is the wage penalty a result of events in the workers employment history, i.e. do workers already experience a wage decline before they enter into temporary agency work, and, closely related, are there stigma effects which can be attributed to the acceptance of a temporary agency job? Finally, the paper analyses whether the unionization of the sector affected the temp wage gap.

\section{Review of the literature}

From a theoretical point of view, the sign of the wage differential attached to temporary agency work is not clear-cut. According to the theory of compensating wage differentials (Rosen 1986), wages of temps should compensate for undesirable job characteristics, like the lack of representation by unions, lack of coverage by the social security and health system, and often lack of vacation entitlement. Temporary help jobs are in general of markedly short tenure (Antoni and Jahn 2008); temps face a higher unemployment risk and have to expect greater income volatility (Segal and Sullivan 1997). In addition, there is some indication that temps are more exposed to risk factors than permanent workers (Storrie 2002, Pedersen et al. 2005). All these unfavorable job characteristics should result in higher wages in the temporary help industry. Comparable higher wages are also to be expected in tight labor markets, where temporary agency firms should have difficulties to recruit workers. To provide an incentive to accept a temporary agency job, they need to offer favorable working conditions and higher remuneration.

On the other hand, there are several arguments justifying why temporary help firms pay less: First, temporary agency employment has some of the same features as an investment. It is often argued that employment spells in temporary help agencies increase workers' human capital and provide the opportunity to gain work experience. While being on assignment, 
temps can develop labor market contacts that lead to stable employment or at least to longerterm employment with higher remuneration (Jahn 2007, Houseman et al. 2003). The outcome of these investments in terms of improved future employment and wage prospects accrues mainly to the worker. Human capital theory therefore would predict that the worker also has to bear the costs by accepting lower wages while being employed in the temporary agency industry, where they merely accumulate general human capital (e.g. Becker 1964).

Second, temps may also profit from the placement activity of the labor market intermediary, which decreases their search costs and improves match quality. In a well functioning labor market, temps must pay a premium for this service. But often temps face credit market rationing, because they may have been unemployed previously. The wage penalty can be seen as a compensation for this service (Jahn 2004).

Third, employers may invest less in temp workers' training or in capital equipment to enhance temp workers’ productivity. As a consequence, their marginal productivity and remuneration may be lower. Fourth, temp workers may be less career-oriented or less motivated. Therefore, they may invest less in firm-specific human capital and are less productive. Fifth, it is well known that temps often are employed below their qualification level, which may justify a lower remuneration as well. Finally, as Blank (1998) points out, firms may also pay wages below the productivity of the workers, because they are able to exercise monopsony control over the wages of workers filling the bottom tier of a two-tier pay structure.

Regarding the size of the earnings after a temp worker left the sector, the theoretical literature also does not provide consensus. In order to attract high ability workers, temporary help firms might offer a package of free general training instead of paying higher wages. Able workers are prepared to accept these packages in expectation of wage gains in a later regular employment relationship. Autor (2001) argues that economies of scale predispose temporary agency firms to provide up-front general training to their workers to a higher degree than regular firms can do. It may therefore be possible that temps are able to acquire more human 
capital than most workers for a given period of time. In addition, while being assigned, temp workers may be able to gain useful information about the particular occupation they are well suited for (Segal and Sullivan 1998). Such information and training may be accompanied by lower wages while working for a temp firm, but may result in an increase of wages in posttemp employment. In addition, firms increasingly use temporary agency employment as a screening device. If the client firm takes over a former temp worker, it is likely that the worker will receive the same remuneration than a directly hired worker. The reason is that two-tier wage structures within a firm may create motivational problems associated with paying similar workers at different rates (Houseman et al. 2003). Alternatively, temp workers may be stigmatized in the sense that future employers may perceive a previous temp spell as an indicator of lower ability and motivation of the worker. This negative signal may result in fewer offers and job offers with lower wages than other workers would receive (Blanchard and Diamond 1994).

To sum up, it appears to be an empirical question whether workers have to accept a wage penalty during a temp spell and must accept lower wages due to stigma effects after leaving the temporary help sector.

There are numerous studies for the US providing evidence for a wage gap between temps and non-temps. Using data from unemployment insurance records of the state of Washington for the period of 1984 to 1994, Segal and Sullivan (1998) estimate a wage penalty of about 10 percent after controlling for both levels and trends of unobserved characteristics. One drawback of the study is that they could not control for worker characteristics or the occupation of the worker. Segal and Sullivan (1998) explain one part of the wage gap by pre-temp earnings: The relative wage of temps already declined before they accept a job in the temporary help sector. In addition, they provide evidence that workers may accept a temp job because it opens possibilities to find a subsequent job match with the same wages as non-temps. One 
quarter after leaving the temp help industry, the wage gap is still about five percent. The wage disadvantage disappears entirely after five quarters. ${ }^{1}$

However, Autor and Houseman (2005), using a random assignment of TANF recipients, cannot confirm that temp workers' remuneration increases after the temps have left the temporary help sector. In contrast to these results, Heinrich et al. (2008) provide evidence for welfare to work recipients that temps fare better in terms of earnings and earnings growth after leaving the temporary help sector and that temp income is associated with better outcomes than not working at all. Using the Longitudinal Employer Household Dynamics program of the U.S. Census Bureau, Andersson et al. (2007) estimate the impact of temp employment on subsequent employment outcomes for five states for the late 1990s. Temps suffer from lower earnings than other workers while working for a temporary help agency. Furthermore they confirm earlier findings that temps can considerably improve their income in a subsequent job, if they find stable employment outside the temporary help sector.

Cohen and Haberfeld (1993) estimate lower returns to human capital investments for Israeli temp workers in some occupations, but not in others. They report an average wage gap of 8 percent in 1983. However, temps working as typists and bookkeepers have a wage advantage of about nine and 15 percent, respectively. By contrast, temps working as clerks and keypunch operators had to accept a wage penalty of 32 and 16 percent.

The evidence for European Countries is rather mixed. Forde and Slater (2005) report an average wage gap of nine percent for the British temporary help service sector in 2000 after controlling for occupation, worker and job characteristics. Male temporary agency workers are paid 11 percent less and female temp workers are paid six percent less than equivalent permanent workers.

\footnotetext{
In an earlier study, Segal and Sullivan (1997) report an average wage gap of 3 percent for temps and workers working for professional employer organizations. Because the data set used suffers from severe misreporting, the study is not discussed in greater detail. See Dey et al. (2006) for further information about identifying temps in US data sets and risks of misreporting.
} 
Portuguese temps have to accept a wage differential of about two percent during 1995 to 2000 (Böheim and Cardoso 2007). The wage gaps differ markedly among labor market groups. Younger workers earn between one and four percent more than comparable permanent workers, whereas prime age men have to accept five percent lower wages. The remuneration of the latter group deteriorates by three percent before they enter into temp jobs. Stigma effects after accepting a temp job cannot be proved for young workers; but there is some evidence that prime age workers experience a slower wage progression after leaving the temporary help industry.

Apart from some studies reporting descriptive wage differentials in Germany, there are two studies for Germany estimating the wage penalty for temps. Based on data from a mediumsized company in the service sector, a recent study by Oberst et al. (2007) estimates a wage gap of 29 percent for temp workers for 2005. The results are only a rough indicator for the wage gap temp workers have to accept. Among the 500 employees, only 43 employees were employed as temps. Lack of information precludes controlling for occupation, tenure or the employment history of the temp workers. Based on the IAB Employment sample (IABS), Kvasnicka and Werwatz (2002) estimate wage differentials and pre and post-earnings for temp workers for Western Germany for the period 1980 to 1990. The authors find a 17 percent wage gap for men and 19 percent for women. The authors do not estimate occupation specific wage gaps, but differentiate between the formal contractual status of the worker. Male "blue-collar" workers have to accept the highest wage penalty (24 percent), whereas male “white-collar” workers accept a 9 percent lower wage. In addition, Kvasnicka and Werwatz (2002) estimate pre-earnings of temps before entering the temporary help sector. They find that temp workers already suffer from a wage decline before entering temporary help employment. After taking the most recent pre-earnings of temps into account, the estimated wage gap reduces to 12 percent for men and 10 percent to women. 
This paper follows the methodological approach of the displacement literature (e.g. Jacobsen et al. 2003) in estimating pre and post-earnings of workers after an unfavorable event has taken place. Compared to the most closely related study of Kvasnicka and Werwatz (2002), the present paper differs in several respects. First, it estimates the wage gap for temp workers after the regulations on temporary agency employment were relaxed significantly. Second, the paper takes a closer look on the wage gaps of Eastern German workers, which may differ from the wage gaps of Western German workers. Third, numerous researchers presume that temps earn lower wages because they are less motivated and career-oriented. This paper takes career-orientation into account by controlling for the workers' employment history of the past five years, in addition to socio-demographic and job characteristics.

Moreover, this paper sheds light on two further questions: First, does the wage differential vary according to occupation and the tightness of the skil- specific labor market? It is to be expected that temp workers specialized in the tight segment of the market have to accept lower wage gaps compared to less skilled workers accepting temporary agency jobs to buy themselves into the labor market.

Second, it is often argued that the lack of bargaining power of temps is one factor why temps may not be able to capture compensation for higher flexibility. Unions were virtually nonexistent in the temporary help service sector in Germany prior to 2002. As a consequence of the recent reform of the law regulating temporary agency employment, wages in the temporary help sector were subject to collective bargaining between unions and employer associations. The change of law gave agencies a high incentive to pay their workers according to a collective agreement. This policy change can be seen as a quasi experiment. Because only temporary agency workers were affected by this reform, it is feasible to evaluate whether lack of bargaining power is one decisive factor for the high temp wage differentials in Germany. 


\section{The German temporary help sector}

In Germany, temporary agency employment is regulated by national legal statutes. The socalled "Labor Placement Act” governs this sector, with specific regulations applying only to temporary help agencies. As in many European countries, German law prohibits temp workers from replacing workers on strike and prohibits temp work in the construction sector (Arrowsmith 2006). German temporary help agencies are obliged to apply to the Federal Employment Agency for authorization to operate. The temporary help industry is made up primarily of small and medium-sized companies. In 2007, nearly three out of four agencies were small firms with less than fifty employees. In this respect, the German temporary help industry does not differ from those in other countries (CIETT 2002). Large temporary help agencies place mainly unskilled and seasonal workers. Some smaller agencies specialize in particular industry sectors and market niches that require university graduates. Many of these are skilled workers in information and communication technology and engineers who are assigned to large-scale projects with a limited time horizon.

Since the Labor Placement Act came into effect in 1972, it has been amended several times. ${ }^{2}$ In April 1997, a new regulation of the temporary help service sector took effect, which consisted of three parts: First, the maximum period of assignment, which determines how long a temp may be assigned to a user firm without interruption, was extended from 9 to 12 months. Second, temporary help agencies were allowed to conclude fixed-term contracts. A fixed-term contract could be prolonged three times until total employment duration added up to 24 months. Third, the reform relaxed the synchronization ban in the sense that an agency was now allowed to conclude an employment contract for the duration of the first assignment. $^{3}$

\footnotetext{
This section concentrates only on the regulations after 1997. A detailed description of the reforms of the law regulating temporary agency employment since the 1980s can be found in Antoni and Jahn (2008).

3 In 2002, the maximum period of assignment was extended from 12 to 24 months. In addition, this reform applied the principle of equal treatment starting in the $13^{\text {th }}$ month of an assignment. Given that most placements last less than six months, it is likely that this reform never had any practical effect (Antoni and Jahn 2008, Bellmann et al. 2003).
} 
The most recent reform in 2003 was intended to strengthen the rights of temporary help workers by applying the principle of equal pay starting with the first day of an assignment. The new law allows deviation from the principle of equal treatment, if the agency applies the conditions stipulated in a sectoral collective agreement to all its temp workers. As a consequence, wage gaps between temps and the permanent staff of a user firm are permissible, if the wages established in the user firm's collective agreement are higher than those in the temp industry’s collective agreement. In addition, by signing a collective agreement, the agency can free itself from all other regulations. As a consequence, numerous collective agreements were concluded in anticipation of this legal reform. The sector had very few collective agreements prior to 2002. By the end of 2003, nearly 97 percent of all temporary help agencies paid their temps according to a sectoral collective agreement. Consequently, the principle of equal treatment and all other regulations have lost any practical meaning for the temporary help industry. As mentioned in the introduction, this sudden "unionization" of this sector should have had an effect on the size of the wages of temp workers, a question which is addressed in Section 5.3.

\section{Data set and descriptive evidence}

\subsection{Data}

The empirical part of the paper uses the IAB Sample (IABS), a two percent random sample of all German employees registered with the social security system covering the period 19752004. The IABS provides information on socio-economic and job characteristics at the individual level. Supplementary information on unemployment benefit recipients is added to the sample. Being of administrative nature, the IABS provides accurate longitudinal information on the workers employment and unemployment histories. Reported wages are used to calculate social security contributions of the employers and are highly reliable. Thanks to its large 
size and the reliability of the wage information, the IABS is well suited for the analysis of wage differentials. ${ }^{4}$

Nevertheless, the IABS has also some limitations for the purpose of this study: First, employment spells in temporary help agencies are identified by an industry classification code. This implies first that no information is available on the client firm where the worker is actually assigned. Second, temporary agency workers cannot be distinguished from agencies’ permanent administrative staff, which accounted for about five to seven percent of agency employees in 2003, depending on the size of the firm (Jahn and Wolf 2005).

Second, civil servants and self-employed workers do not contribute to the social security system and are therefore not covered by the sample. This shortcoming should not affect the results, as temps are usually not hired to perform tasks done by civil servants. There is also no indication that, compared to other workers, temps leaving or entering the sector have been or will be disproportionally self-employed after entering or leaving the sector.

Third, since gross wages can only be observed up to the social security contribution ceiling, about three percent of the employment spells are right-censored. This may affect the estimates in the highly-skilled segments of the labor market. We therefore use imputed wages above the social security contribution ceiling using a heteroscedastic single imputation approach specifically developed for the IABS data set by Büttner and Rässler (2008). All wages are deflated by the CPI (base year 2005).

Third, the dataset reports gross daily wages and does not provide information on the hours worked. We therefore exclude part-time employees, marginal employees, interns and homeworkers from the sample, since the wage information is not accurate for these groups. For the same reason, we exclude workers with wages below the social security contribution threshold. In contrast to the USA and some other European countries, temporary help jobs in Germany

\footnotetext{
4 For the period 1992 to 2004, it records more than 10 million employment spells and nearly 2 million benefit spells.
} 
are rarely second or part-time jobs (about 5 percent). Therefore, we do not expect that the exclusion of these workers affects the results.

Fourth, trainees are excluded as they belong to regular agency staff and are not assigned to user firms. Fifth, the analysis is restricted to employees between the ages of 17 and 60 . The first reason is that we want to exclude students working during the summer break. Second, the statutory retirement age for females is the age of 60 , for males 65. Sixth, following Brücker and Jahn (2008), we coded ethnic German immigrants as foreigners, because their human capital and employment history may be closer to that of foreigners.

The information on education is provided by the employers in the IABS. This means that information on education levels is missing for about 17 percent of the individuals. Temps are slightly disproportionally affected by missing information on education levels. We therefore imputed the missing information on education by employing the procedure developed by Fitzenberger et al. (2005) for an earlier version of the IABS. In a first step, spells with valid and invalid educational information are identified by classifying the reliability of employers' reporting behavior. In subsequent steps, only valid educational information is used for extrapolation. This procedure allows us to correct inconsistent education information on individuals over time as well. After applying this imputation procedure, we had to drop only 1.5 percent of the individuals due to missing or inconsistent information on education.

Finally, we restrict the analysis to the period 1992 to 2004. There are two reasons for this decision: First, Eastern Germany is only included in the data-set after 1991. We use the information for the period 1992 to 1996 to control for the employment history of the workers of the previous five years. This allows us to estimate wage gaps for the period 1997 to 2004. The period for estimating the wage differentials was also chosen with respect to a fundamental reform of the law regulating temporary agency work in 1997 (see Section 3).

We confine our analysis to workers employed on September 30. This date is far enough away from the recent change of the law on temporary agency employment and should permit 
to identify the reform effect. Employers are only required to report the total wage paid to a worker once a year. Thus, we used yearly data to estimate the wage gap. To construct the workers' employment history, we took advantage of the daily spell structure of the dataset.

\subsection{Definition of variables and descriptive evidence}

The dependent variable is the real log gross wage of the workers. To identify the wage differentials, we include a dummy variable, which takes on the value 1 , if a worker is employed at a temporary help agency, and zero otherwise. In addition, we control for individual and firm characteristics as well as for macroeconomic variables.

As socio-demographic variables are available: Sex, age, age squared, and nationality. To measure the skill level of temporary help workers, we use six educational variables: secondary degree without vocational training, secondary degree with vocational training, high school degree without vocational training, high school degree with vocational training (reference category), polytechnic and university degree.

Although our data set provides rich information at the individual level, we have to assume unobserved heterogeneity influencing the wage level, for example with regard to career orientation and social skills. We use previous employment history as a proxy for these characteristics by including the following categories: Previously registered as unemployed, employed in temporary agency work, and otherwise employed (base category). Individuals without previous information for more than 30 days before starting a new job are coded as previously outside the labor force. In addition, we controlled for the duration of the previous labor market status by constructing three classes: 0 to 6 months (base category), 6 to 12 months, and more than 12 months. In addition, we controlled for the employment duration of the current job in months, employment duration in the current job squared in months, the aggregated employment duration in months during the past five years, the number of jobs and temp jobs held during the past five years. 
The IABS provides detailed information on the predominant occupation of the worker, which is used as an indicator of the industry to which the worker is assigned. Because the tasks of temps may vary between assignments, we use a broad classification and differentiate between six occupational groups: The first are the technical occupations with highly skilled workers (engineers, mathematicians, and chemists), the second are service occupations, and the third are clerical occupations. In addition, we divide the manufacturing occupations into three variables because of evidence that particularly the German metal industry (e.g., automobile and aircraft industry) uses temps to circumvent the high wages agreed upon in collective bargaining. We therefore first pool all typical occupations in the metal industry in the dummy variable "manufacturing occupations in the metal industry," our fourth group. Then we aggregate laborers without a specific occupation, but belonging to the manufacturing occupations as well, in a separate dummy variable, the fifth group. The sixth group "other manufacturing occupations”, the base category, includes all remaining workers.

To account for heterogeneity among the agencies, we included five firm size classes. The largest class, firms with more than 200 employees, acts as the reference category: The capability of an agency to deal with short-term demand shocks depends on the number of its client firms and on the extent of diversification between the clients' economic sectors. Thus, there will likely be a positive correlation between firm size and wages in the respective firm.

We also include three variables that capture the percentage of temp agency employees with a university degree, with no vocational training and with vocational training (base category). As mentioned in Section 3, some agencies specialize in providing highly skilled temps for sophisticated tasks. The fraction of university graduates serves as a proxy for the probability of being employed in such a specialized agency. The use of this variable is based on the hypothesis that workers employed in these temp agencies are more likely to obtain assignments that match their qualifications. As a consequence, we expect that the wage gaps of workers in these firms are lower. 
As macroeconomic variables, we use, first, the real annual growth rate of GDP, because the demand for temporary agency workers varies with the economic cycle; second, 12 dummy variables at the regional level indicating the tightness of the regional labor market; and third, three variables indicating whether a worker works in an metropolitan, an urban or rural area. ${ }^{5}$

[Table 1 about here]

Table 1 provides some descriptive statistics on selected variables. In our analysis we are able to include 3,124,329 spells, among them 43,031 temporary agency work spells, and 611,369 workers; 23,365 workers worked as a temporary help worker at least once during the period 1997-2004. Table 1 shows that temp workers on average earn less than regular workers. The average daily real gross wage of temp workers is 53 Euros during the observation period, the average wage for regular workers 96 Euros.

Most temporary help workers are male (76 percent), which is true for our entire observation period. Compared to the share of non-German workers in overall employment, which amounts to nine percent, foreigners are overrepresented in temporary agency jobs at 21 percent. The average age of temp workers (35 years) is lower than in the comparison group (39 years). Workers without vocational training are overrepresented in temporary agency employment (20 percent), compared to their share in regular employment (10 percent).

About two thirds of all temps are employed in manufacturing or as laborers. In contrast to most European countries, service jobs and clerical occupations do not play an important role in the German temporary help sector. One out of four temp workers and one out of five regular workers had previously been out of the labor force and therefore appeared to have only a loose attachment to the labor market. About 40 percent of the temp workers were previously unemployed, whereas only 15 percent of the non-temps experienced an unemployment spell before they accepted their current job. More than 60 percent of the regularly employed work- 
ers had been regularly employed before their current job, which is true of only about 20 percent of the temp workers.

\section{Empirical strategy and estimation results}

\subsection{Wage gap of temporary agency work}

Depending on the data at hand, different evaluation strategies can be thought of (Heckman et al. 1999, 2005). Given that rich administrative data are available, approaches relying on the selection of observables assumption, like the matching model, and regression techniques are to be considered. Missing information about most common variables measuring the household context, like marriage status and number of children living in the household, makes it quite impossible to justify a matching approach. Instead, we use a fixed effects model, which is commonly used to estimate wage gaps for different labor market groups (Heckman et al. 2005). The main advantage of the fixed effects estimator for our purpose is that it allows for self-selection into temporary agency employment based on the time-invariant component of the unobservables, and it does not require strong distributional assumptions (Wooldridge 2002).

In order to get a first approximation of the average wage gap in temporary help employment, we estimate the following simple regression model:

$$
w_{i t}=\alpha_{0}+\tau_{t}+\beta D_{i t}+\lambda z_{i t}+\varepsilon_{i t},
$$

where $w_{i t}$ is the log of the real wage for worker $i$ in year $t$. The $\tau_{t}$ 's are the coefficients of a set of dummy variables for each year in the sample period that capture the general time pattern of earnings in the economy, $D_{i t}$ is a dummy variable that is one when the worker is employed by a temporary help agency firm and zero otherwise, and $\beta$ is the impact of temp work. $z_{i t}$ is a set of yearly interaction terms for temporary agency work and $\varepsilon_{i t}$ is the error 
term with the usual properties. We estimate the parameters of (1) by least squares. This model estimates the difference in mean wages between temps and regular workers.

[Figure 1 about here]

Figure 1 displays the mean wage gap for temporary help workers in Eastern and Western Germany in percent. The first striking result is that the wage gap exhibits an upward trend during the entire observation period, starting with 38 percent in 1997 and increasing up to 43 percent in 2004. This result confirms earlier findings by Kvasnicka and Werwatz (2002), who find a widening wage gap for the period 1980-1990 as well. First of all, the rising wage gap is a consequence of a real wage increase for regular workers of about eight percent during the observation period and second of a real wage loss for the temporary agency workers of about six percent.

Second, the wage gap for Eastern Germany is considerably lower than that for Western Germany. This difference may be a result of two facts: The general remuneration of East German workers is still considerably below that of West German workers. ${ }^{6}$ At the same time, the reservation wage at which a worker is willing to accept a job is set by unemployment benefits and unemployment assistance. In order to attract workers, the temporary help agency sector has to pay a wage that is equal to or above the reservation wage. With respect to this bottom line, it seems that the temporary help service sector could not lower the temp wages further. Another explanation may be that, as a result of the higher unemployment rate in Eastern Germany, workers may be more willing to accept temp jobs which occupational requirements are far below the present human capital of the worker doing the job. In this case, their productivity will on average be higher compared to West German temps.

Third, during the observation period, which covers roughly one business cycle, there is no cyclical pattern visible. Finally, as pointed out earlier, we would have expected that the wage

The considerable wage differential of about 30 percent between Eastern and Western Germany is usually explained by the huge excess of labor supply in Eastern Germany, the lower productivity of workers who stayed in Eastern Germany after reunification, and the fact that most firms in Eastern Germany do not pay according to collective agreements. 
gap decreases after 2003 as a consequence of the unionization of the temporary help service sector. The descriptive results in Figure 1 do not confirm this expectation.

To get a more detailed picture, we include individual worker characteristics in an OLS model, specifically age, age squared, education, regional dummies, the BIP growth rate, firm size and a set of time dummies. To this specification, we add stepwise the occupation of the workers and the previous employment history as described in Section 4.1. As pointed out earlier, the inclusion of the occupation and the employment career variables may be important to get a more precise estimation of the wage penalty temp workers have to accept. Equation (1) is modified to:

$$
w_{i t}=\alpha_{0}+\tau_{t}+\beta D_{i t}+\gamma x_{i t}+\varepsilon_{i t}
$$

The vector $x_{i t}$ consists of the observed worker and job characteristics as well as the occupation and the employment history of the worker.

It is well known that participation in the temporary help sector is not random. Temps rather differ from regular workers in numerous dimensions. In a next step, we take advantage of the longitudinal nature of the data-set by including worker specific dummies. By this, timeinvariant differences in the characteristics of workers can be controlled for. In this case, the specification of the model is

$$
w_{i t}=\alpha_{0}+\tau_{t}+\alpha_{i}+\beta D_{i t}+\gamma x_{i t}+\varepsilon_{i t},
$$

which differs from (2) by the inclusion of a constant for each worker. The fixed-effect, $\alpha_{i}$, summarizes the impact of permanent differences among workers in unobserved characteristics.

The results of this stepwise procedure are summarized in Table 2. In general, the results confirm our descriptive result that the wage gap in Western Germany is larger than the wage 
gap in Eastern Germany. Male temp workers have to accept a higher wage penalty than female workers. In addition, Table 2 shows that the inclusion of the occupation slightly reduces the wage gap. The inclusion of the recent employment career reduces the estimated wage gap in all estimations by ten percent. This result documents, that every estimation of wage differentials for temp workers failing to include the employment history may overestimate the true wage gap. In addition, model (3) in Table 2 reveals that the wage gap for temps is rather high, even after controlling for observable worker characteristics, and that it differs between male and female workers. Whereas male workers have to accept 23 percent lower wages, female workers must accept a wage penalty of 17 percent. The finding that female temps have to accept a lower wage penalty than men also remains stable after we divided the sample into Eastern Germany and Western Germany. The reason may be that women, who only represent the minority among temp workers, more frequently work as clerks. It is likely that their human capital matches the requirement of the temp job at hand more often. Nevertheless, in light of the existing international empirical evidence, summarized in Section 2, the German temp wage gap of 16 to 25 percent estimated so far is very high and is not in line with the standard model of compensating wage differentials.

[Table 2 about here]

The last specification (model 4) in Table 2, which controls for unobserved heterogeneity, further reduces the wage differentials for all workers from 22 to 20 percent, but the effect is not very pronounced compared to the previous OLS specification. ${ }^{7}$ It seems that including the employment career of the worker captures a large part of the heterogeneity between temp workers and non-temp workers. Nevertheless, the estimate of rho suggests in all cases that almost all variation in the log wages is related to individual differences. The $F$ test indicates

The stata command xttest 3 is used to calculate a modified Wald statistic for group-wise heteroscedasticity in the residuals of a fixed effect regression model (Greene 2003, p. 328). The null hypothesis that there is group-wise heteroscedasticity present can be rejected at the one percent level. 
that there are significant individual effects, implying that pooled OLS would be inappropriate. Therefore, we only discuss the results from the fixed effects estimations here.

The individual constant term in a fixed effects panel regression model usually measures unobserved heterogeneity, such as social skills and the motivation of the workers. Temp jobs in Germany are of exceedingly short duration (Antoni and Jahn 2008). It is plausible to assume that temp workers are usually less motivated, they are less linked to their employer and they presumably invest less in firm-specific human capital. In addition, the motivation to accept a temp job may not be to build up a long-lasting employer-employee relationship; instead, there is some evidence for Germany that some temp workers indeed favor temp jobs because of their inherent flexibility and reduced expectation of commitment to the employer (CIETT 2002).

Surprisingly, in the case of female temps the wage differential increases after fixed effects are included in the estimation, indicating that female temp workers are more highly motivated than their non-temp counterparts. Why should they be more motivated? Female temps more often accept a temp job after an interruption in their employment career, e.g. in order to take care of the children. After such a break, it is often hard for women to re-enter into the labor market. It may be plausible that they more often accept a temp job as a stepping stone into regular employment compared to men. Therefore, women may work harder and invest more in firm-specific human capital than male temp workers in the hope that the temp firm will be willing to offer them a follow-up job or to be taken over by the client firm.

[Table 3 about here]

Some labor market groups tend to fare differently in the labor market. Table 3 reports the wage gaps for different worker characteristics and the size of the local labor market. The results indicate that workers below the age of 20 earn 17 percent less than their full-time regular counterparts. Compared to the wage differential of the full sample, it is considerably lower. 
The same holds for workers which are older than 55 years. To investigate whether the wage gap varies between education, we summarized the six educational groups into three groups: without vocational training, with vocational training and with a university or polytechnic degree. It seems that the wage gap does not vary according to the education of the worker.

In addition, Table 3 reveals that the wage gap depends on the size of the local labor market. Temporary agency help firms are traditionally operating in large metropolitan areas. Recently, there has been a suburbanization process taking place (Jahn and Wolf 2005). Temporary agency firms in rural areas are usually smaller in size and serve only few clients, which frequently demand a larger bundle of temp workers. Table 3 shows that temp firms located in large metropolitan areas pay their temps less than temp firms in rural areas. There, the wage penalty is only about 17 percent. One reason for this difference could be that social networks are more important in rural areas. Workers living in the countryside are better informed about the wages comparable regular workers receive. Therefore it may be more difficult for temporary help agencies to execute their monopsony power. Once it is evident that a temp firm pays considerably lower wages, it will have a hard time to find workers willing to work for the agency.

[Table 4 about here]

It is a well known stylized fact that the remuneration increases with the size of the firm. This is also the case in our fixed effects estimation for all workers. Contrary to this common wisdom, the remuneration in the temporary help service sector decreases markedly with firm size. Whereas temps working in small temporary help firms (below 20 employees) have to accept a wage penalty of about 13 percent, the wage gap increases to about 24 percent for workers in large firms (over 200 employees). One reason might be that large temp firms are more prone to offer general training before sending their workers to a client firm. At least one part of this investment may be covered by the lower wage of the temps (see Section 2). There 
is some anecdotal evidence that large temporary agency firms indeed provide more training to their workers than small temp firms do. In addition, social norms and values, like "fairness" considerations, may be more important in small agency firms when it comes to bargaining over the wage. Finally, as pointed out in Section 3, smaller agencies are more often specialized in small market niches. This specialization may allow them to pay higher wages to their workers than larger agencies can pay, which may have to face more competition. The higher wage penalty in large firms may also be caused by the fact that they can exercise their monopsony power more easily.

In Germany, one of the huge demanders of temp workers is the metal sector, particularly the automobile, aeronautical and shipping industry. They usually need workers trained in metal occupations. In addition, it is said that these industries use temp workers not only to increase flexibility, but also to circumvent the high wages agreed in collective agreements. This motive may be most important in the metal industry, because the metal unions play a pioneering role in Germany when it comes to collective bargaining. According to this argument, the client firms' motivation to employ temp workers is mainly driven by the desire to use temp workers as a cost-cutting instrument. Table 4 does not provide any evidence that workers in the metal industry have to accept a higher wage penalty than temps working in other occupations.

In the introduction, the "knowledge argument" was stressed according to which some temp workers exercise highly specific tasks. These workers prefer to work as temps in order to earn more by working on a flexible basis. The results in Table 4 confirm that the wage gap for technicians is considerably lower compared to the average. Nevertheless, the wage gap is still large at 13 percent and cannot support the argument that employees work as technicians at temporary agency firms in order to increase their remuneration. 


\subsection{Pre- and post-earnings}

As is already evident from Table 1 , temp workers often accept a temporary job after some interruption in their employment career. About 66 percent of all temps received previously unemployment benefits or have previously been out of the labor force. Even though we controlled for the employment history of the past five years, such events may be associated with reductions in wages that would reflect circumstances that lead them to accept temp work.

In this section, the paper follows Jacobsen et al. (1993) by taking into account pre and post-earnings of the temps. To do so, we construct a set of dummy variables representing years before or after a spell in temporary agency work, respectively.

$$
w_{i t}=\alpha_{0}+\tau_{t}+\alpha_{i}+\sum_{k \geq-3}^{3} \beta_{k} D_{i t}^{k}+\gamma x_{i t}+\varepsilon_{i t}
$$

If year $t$ is $k$ years after the temp spell, then $k>0 ; k<0$ in years before the temp spell started. $\beta_{k}$ is the effect of temp employment on worker's earnings $k$ years preceding or following its occurrence. To avoid any distorting effect of earlier temp spells on wages, we include only workers without temp spells five years before the observation period starts and who had only one temp episode, defined as the sequence of consecutive years in which a worker holds a temp job.

In addition, we exclude the period 2003 to 2004 from our analysis for two reasons: First, to insure that the wages are not affected by a temp spell right after 2004, which cannot be observed yet in our dataset but will affect the wages in 2004 and 2003. Second, we want to exclude effects on earnings as a consequence of the reform in 2003. Thus, we allow $k$ to range between -3 and 3 , implicitly assuming that $\beta_{k}=0$ more than three years removed from the temp spell. ${ }^{8}$

\footnotetext{
As a robustness check, we let range $|k|$ between two and four. In addition, we run the estimations including only workers who had observations for all six years. It turns out that the results are still robust.
} 


\section{[Table 5 about here]}

Table 5 documents that, compared to the fixed effects specification (4) in Table 2, the estimated wage gap is slightly higher in magnitude after we limited the sample as described above. The only exception is Eastern Germany, where it increased markedly from 17 percent to 20 percent. Furthermore, Table 5 shows that temp workers indeed suffer from a wage decline already before entering the temporary help service sector. Three years before entering the sector, workers had to accept a wage gap of between two and four percent. The wage gap increases up to seven percent one year before entering the temporary help service sector.

After successfully leaving a temp job for a permanent position, the wage gap decreases and amounts only to between one percent for male West German temps and three percent for female workers and East German temps. Two years after leaving the sector, the former temps caught up and do not have to accept lower earnings than their permanent counterparts. Of course, these figures only hold for a subset of the temp population, namely the temp workers who have found a permanent position after leaving the temporary help service sector.

Regarding the lower pre-temp earnings, the results are in line with the existing literature. But the results differ regarding the size of the wage penalty. Segal and Sullivan (1998) find a wage penalty of about two percent four quarters before entering the temporary help service sector, Böheim and Cardoso (2007) report a four percent wage penalty and Kvasnicka and Werwatz (2002) estimate a wage decline of nine percent for male workers and 14 percent for female workers.

Regarding the post-temp earnings, our results are more in line with Segal and Sullivan (1998). American temp workers need eight quarters to catch up. Portuguese workers still must accept a wage penalty of two percent two years after leaving the temp sector (Böheim and Cardoso 2007). According to Kvasnicka and Werwatz (2002), German temp workers already catch up one year after the last temp job has ended. The difference between our result and the 
latter study is that the latter only allowed one temp spell during their observation period, while in this study the temp episode also includes consecutive temp spells, as long as the temp episode is not interrupted by unemployment or a period of permanent employment.

The marked decline of temp wages one period before entering the temporary help sector indicates that the earning potential of temps at the time they enter into the sector is lower compared to that of their non-temp counterparts. Therefore, the estimated wage differentials reported in Tables 3 to 5 may only be seen as an upper limit for the true wage gap. Unfortunately the counterfactual, i.e. the earning potential of temps not working as temps, is not observable. Instead, we take the earnings of temps one year before entering the sector as an approximation. After taking the pre-earnings potential into account, the last column in Table 5 shows that the wage differentials decline to 15 percent for East German temps and 18 percent for West German temps.

\subsection{The effect of collective agreements in the temporary help sector}

In a last step, we test whether the recent reform at the beginning of 2003 had an effect on the remuneration of temps. Within the individual fixed effects framework, we are able to estimate the causal effect of the reform on the wage differential for temps by means of a difference-indifference specification. To do so, we include a time dummy for the period 2003 - 2004 and an interaction term for the reform dummy with the temp indicator. The parameter estimates of the interactions of the reform and the time dummy indicate whether there is a causal effect of the reform on the wage gap.

\section{[Table 6 about here]}

Table 6 first of all shows that real wages decreased about two percent for the entire economy after 2003. The wage decline was much more pronounced for temp workers than for regular workers. In addition, temps had to accept a drop in earnings of about five percent. 
Table 6 furthermore documents, that this result is also stable, if we divide the data-set according to East and West German temps and female and male temps. ${ }^{9}$

Contrary to the expectation, the results indicate that the collective agreements in the temporary help sector could not bring a halt to the widening wage gap between temp workers and non-temp workers. On the contrary, it seems that the new legislation was used by the temporary help service sector to decrease wages further.

Nevertheless, collective agreements often impose work rules, such as breaks after a predefined period of continuous work at the assembly line, number of vacation days, paid overtime, pension benefits or minimum training requirements, which was also the case after collective agreements were introduced in the German temporary help service sector. These benefits usually increase the quasi-fixed costs of labor and can be seen as non-wage benefits for temps. The data at hand do not provide any information of that kind. Therefore, one should be cautious in concluding that the reform worsened the general working conditions of the temps.

\section{Conclusions}

As in most European countries, in Germany temporary agency employment experienced a considerable growth during the past decade. Recent statistics indicate that nearly three percent of the dependent workforce is working in the temporary help sector. The reasons for this shift away from permanent positions are unclear, but it seems that user firms increasingly enjoy the flexibility to modify their workforce, if in need. Accepting a temporary agency job can be rewarding, as temps can explore different types of jobs, often with a reduced expectation of commitment to the employer. Temp jobs may also be helpful to bridge gaps between two permanent jobs, and they even may be a stepping stone into regular employment for some temps. This is the bright side of temporary agency work. But there is a shady side as well.

During the year 2003, temporary help agencies could choose between using the old regulatory framework or applying collective agreements. As a robustness check, we therefore run the estimations by excluding the year 2003 and using the year 2004 as the reform year. The wage decline is even more pronounced in this specification. 
It is well known that temp workers generally do not enjoy the same working conditions, wages and benefits as their regular full-time counterparts. In fact, the study has shown that this part of the labor force earns less than regular full-time employees. The raw figures suggest that agency workers receive only about 60 percent of the wage compared to their regular counterparts. Much of this difference may be accounted for by variation in the composition of temps and regular workers with respect to age, skills, occupation and other factors related to wage outcomes. To what extent is this the case?

To investigate this issue, the paper estimated fixed effects regression models controlling for a wide range of personal and job characteristics. The results indicate that wage gaps are markedly reduced, if one controls for these characteristics. If one also takes workers' employment history into account, then the wage gap drops further, indicating that studies failing to control for the employment career of workers run the risk to overestimate the wage differential. Nevertheless, temporary agency workers earn between 15 percent and 18 percent less. The study also shows that temp workers are extremely heterogeneous and that their relative wage situation depends on their occupation and the size of the local labor market. However, compared to the prevailing international evidence, the German wage gap remains large and significant for most of the agency workers, suggesting that agency jobs may be of poor quality, at least in terms of remuneration.

The question arises whether these findings have to be seen as a serious cause for concern. Before entering the temporary help sector, two thirds of the temp workers have been unemployed. For most of them, working in the temporary help sector may be better than the alternatives of working in programs of active labor market policy, marginal employment or on the black market. Working in the temporary help sector also increases the chances that temp workers will get at least some training and can keep their hitherto accumulated human capital up to date. This holds at least for these temps, who would otherwise face a period of unemployment. This is the case in Germany. Temporary agency employment indeed reduces the 
unemployment risk for temp workers compared to unemployed not accepting a temporary agency job (Kvasnicka 2008). To put it differently: For most temps, the alternatives are not "working as a temp or as a regular worker”. It seems that the true alternatives they face are “working as a temp or staying unemployed”.

The theoretical literature provides rationale why the remuneration in the temporary help sector may be lower. Temps may accept a wage disadvantage, because they are prepared to pay a premium to the agency for their matching service and the opportunity to build up labor market contacts that lead to permanent employment. In addition, temporary agency work may provide the path for subsequent job matches with better pay. Our results provide at least a first indication that those temps who are successful in finding permanent employment after the temp job has ended do not have to accept a wage disadvantage in the long run. Two years after leaving the sector, these workers receive the same remuneration as comparable directly hired workers.

The legislation for temporary agency workers in Germany has strengthened temp workers’ rights just recently. Since then, a temporary help agency has the choice to apply the principle of equal treatment, implying that the temp receives the same remuneration as a regular worker at the client firm, or pay its workers according to a collective agreement. At first sight, this looks like major progress for those at the bottom of the economic ladder. Examined more closely, our results indicate that the unionization could not bring the widening wage gap to a halt. But the study could not control for other job characteristics that normally improve, if a firm applies the rules of a collective agreement.

There is one final issue to discuss: Is the agency working directive of the European Commission to be welcomed in that it will remove worse working conditions for temps? It is likely that provisions that ensure equal treatment of agency workers will overcome the pay disadvantage associated with agency work for at least a small fraction of temps. But the directive will increase the costs for agency workers as well, by imposing additional administrative costs 
on the agency and the client firm in agreeing what the equal pay will be. It is likely that the ones to suffer will be the temps with the lowest productivity, who will be kicked out from the market by such a regulation. In this context, the results by Böheim and Cardoso (2007) are striking. The Portuguese temporary help sector is highly regulated and agencies are already required to apply the principle of equal treatment. Nevertheless, Portuguese temp workers have to accept wage differentials of significant size. This result may be taken as an indication that the imposition of equal treatment will not preclude wage gaps in the temporary help sector. If one balances the small gains of such a regulation in terms of lower wage gaps against the drawback, namely that some of the temps will lose their jobs it is questionable whether it may be advantageous to further regulate this small segment of the labor market that employs only 2.7 percent of the dependent workers and about 1.8 percent of the total work-force.

\section{References}

Andersson, F.; Holzer, H. and Lane, J. (2007), “Temporary Help Agencies and the Advance Prospects of Low Earners,” IZA Discussion Paper No. 3113, Bonn.

Antoni, M. and Jahn, E. (2008), "Do changes in regulation affect employment duration in temporary help agencies?” Industrial Labor Relations Review, forthcoming.

Arrowsmith, J. (2006), “Temporary agency work in an enlarged European Union.” European Foundation for the Improvement of Living and Working Conditions: Luxembourg.

Autor, D. (2001), “Why do temporary help firms provide free general skills training?” Quarterly Journal of Economics 116, 1409-1448.

Autor, D. and Houseman, S. (2005), “Do Temporary Help Jobs Improve Labor Market Outcomes for Low-Skilled Workers? Evidence from Random Assignments.” NBER Working Paper No. 11743, Cambridge.

Becker, G. (1964), Human Capital, University of Chicago Press, Chicago.

Bellmann, L., Promberger, M. and Theuer, S. (2003), "Verbreitung und Nutzung von Leiharbeit im Jahre 2002 - eine Bestandsaufnahme.” Arbeit und Beruf 54(8), 232-235.

Blanchard, O.; Diamond, P. (1994), “Ranking, Unemployment Duration, and Wages,” Review of Economic Studies 61, 417-434. 
Blank, R. (1998), “Contingent work in a changing labor market,” in: R. B. Freeman and P. Gottschalk, eds, 'Generating Jobs: How to Increase Demand for Less-Skilled Workers', Russel Sage Foundation, New York, 259-294.

Blien, U.; Hirschenauer, F. and Phan, H. (2006), "Model-based classification of regional labour markets for purposes of labour market policy.” IAB Discussion Paper No 29, Nuremberg.

Böheim, R. and Cardoso, A. (2007), “Temporary help services employment in Portugal. 1995-2000.” National Bureau of Economic Research. Working Paper No. 13582. Cambridge. MA.

Brücker, H. and Jahn, E. (2008), “Migration and the Wage-Setting Curve: Reassessing the Labor Market Effects of Migration.” Aarhus School of Business, University of Aarhus, Economics Department Working paper Series, Working paper 08-4, Aarhus.

Büttner, T. and Rässler, S. (2008), "Multiple imputation of right-censored wages in the German IAB employment register considering heteroscedasticity.” in: United States, Federal Committee on Statistical Methodology (Hrsg.), Federal Committee on Statistical Methodology Research Conference 2007, Arlington, 21 S.

CIETT (2002), "Rationale of Agency Work - European Labour Suppliers and Demanders' Motives to Engage in Agency Work”, Rotterdam.

CIETT (2007), “Ciett Statistics 2006”. http://www.ciett.org/fileadmin/templates/ciett/docs /CIETT_2006_Statistics.pdf.

Cohen, Y. and Haberfeld, Y. (1993), “Temporary Help Service Workers: Employment Characteristics and Wage Determination.” Industrial Relations 32, 272-287.

Dey, M.; Houseman, S. and Polivka, A. (2006), “Manufacturers' outsourcing to employment services.” Staff Working Paper No. 07-132. Kalamazoo, MI, W. E. Upjohn Institute for Employment Research.

Eurofound (2007), “Debate on temporary agency work intensifies”. eiro-online. December 2007. http://www.eurofound.europa.eu/eiro/2007/12/articles/uk0712029i.htm.

Fitzenberger, B., A. Osikominu, A. and Völter, R. (2005), ”Imputation Rules to Improve the Education Variable in the IAB Employment Subsample," ZEW Discussion Paper No 0510; Mannheim.

Forde, C. and Slater. G. (2005), “Agency work in Britain: character, consequences and regulation.” British Journal of Industrial Relations 43, 249-271. 
Greene, W. (2003), Econometric Analysis. Fifth Edition, Prentice Hall.

Heckman, J.; LaLonde, R. and Smith. J. (1999), “The Economics and Econometrics of Active Labor Market Programs.” in: Handbook of Labor Economics. vol. III. ed. by Ashenfelder, O.; Card, D., Amsterdam, pp. 1865-2097.

Heckman, J.; Lochner, L. and Todd, P. (2005), "Earnings functions, rates of return, and treatment effects: The Mincer Equation and Beyond.” NBER Working Paper No. 11544, Cambridge, MA.

Heinrich, C.; Mueser, P. and Troske, K. (2008), “The Role of Temporary Help Employment in Low-wage Worker Advancement.” in: Autor, D. ed., Labor Market Intermediation, Chicago: The University of Chicago Press, forthcoming.

Houseman, S.; Kalleberg, A. and Erickcek, G. (2003), “The Role of Temporary Agency Employment in Tight Labor Markets.” Industrial and Labor Relations Review 57, 105-127.

Jacobsen, L.; LaLonde. R. and Sullivan, D. (1993). “Earnings losses of displaced workers.” American Economic Review 83, 685-709.

Jahn, E. and Wolf, K. (2005), "Regionale Verteilung der Leiharbeit - Konzentration oder Diffusion?” IAB Kurzbericht Nr. 14, Institute for Employment Research, Nuremberg. Jahn, E. (2004), “Leiharbeit - für Arbeitslose (k)eine Perspektive?” in: Ungleichheit und Umverteilung. ed. by Aaken. A.; Grötzinger. G., Marburg, 215-236.

Jahn, E. (2007), “Leiharbeit in Deutschland: Phönix aus der Asche?”. in: Kompetenzentwicklung in der Zeitarbeit - Potenziale und Grenzen. ed. by Münchhausen. G., Bonn, 21-44.

Jørgensen, C. (2007), “Precarious situation of temporary agency workers”. eironline. http://www.eurofound.europa.eu/eiro/2006/10/articles/dk0610029i.htm.

Kvasnicka, M. (2008), “Does Temporary Agency Work Provide a Stepping Stone to Regular Employment?” in: Autor, D. ed., Labor Market Intermediation, Chicago: The University of Chicago Press, forthcoming.

Kvasnicka, M. and Werwatz, A. (2002), “On the Wages of Temporary Help Service Workers in Germany”. Discussion Paper No. 70. SFB 373. Humboldt - Universität Berlin. http://sfb.wiwi.hu-berlin.de/papers/2002.html.

Oberst, M.; Schank, T. and Schnabel, C. (2007), “Interne Arbeitsmärkte und Einsatz temporärer Arbeitsverhältniss: Eine Fallstudie mit Daten eines deutschen Dienstleistungsunternehmens.” Zeitschrift für Betriebswirtschaft 77, 1-19. 
Pedersen, H.; Stener, H.; Claus, B. and Mahler, S. (2005), “Temporary Agency Work in the European Union” (report), European Foundation for the Improvement of Living and Working Conditions. Dublin.

http://www.fr.eurofound.eu.int/pubdocs/2004/104/en/1/ef04104en.pdf.

Rosen, S. (1986), “The Theory of Equalizing Differences” in: Handbook of Labor Economics. vol. I. ed. by Ashenfelder. O.; Layard. R., Amsterdam, 641-692.

Segal, L. and Sullivan, D. (1997), “The Growth of Temporary Services Work.” Journal of Economic Perspectives 11, 117-136.

Segal, L. and Sullivan, D. (1998), “Wage Differentials for Temporary Services Work: Evidence from Administration Data”. Federal Reserve Bank of Chicago. Working Paper Series. No. WP-98-23. Chicago.

Storrie, D. (2002), “Temporary agency work in the European Union.” European Foundation for the Improvement of Living and Working Conditions: Dublin.

Wooldridge, J. (2002). “Econometric Analysis of Cross Section and Panel Data”, Cambridge, MIT Press. 


\section{Tables and Figures}

Table 1: Descriptive evidence

\begin{tabular}{|c|c|c|c|c|}
\hline & \multicolumn{2}{|c|}{ Temp workers } & \multicolumn{2}{|c|}{ Regular workers } \\
\hline & mean & sd & mean & $s d$ \\
\hline Real gross daily wage & 53 & 28 & 96 & 57 \\
\hline \multicolumn{5}{|l|}{ Socio-demographic characteristics } \\
\hline Age & 35 & 10 & 39 & 10 \\
\hline Male & 0.76 & & 0.65 & \\
\hline Foreign & 0.21 & & 0.09 & \\
\hline \multicolumn{5}{|l|}{ Education } \\
\hline Secondary degree no voc. training & 0.19 & & 0.09 & \\
\hline Secondary degree with voc. training & 0.67 & & 0.71 & \\
\hline High school degree no voc. training & 0.01 & & 0.01 & \\
\hline High school degree with voc. training & 0.07 & & 0.07 & \\
\hline Polytechnic & 0.03 & & 0.05 & \\
\hline University & 0.03 & & 0.08 & \\
\hline \multicolumn{5}{|l|}{ Previous labor market history } \\
\hline Unemployed & 0.39 & & 0.15 & \\
\hline Unemployed 0-6 months & 0.26 & & 0.10 & \\
\hline Unemployed 6-12 months & 0.07 & & 0.03 & \\
\hline Unemployed > 12 months & 0.06 & & 0.02 & \\
\hline Not in the labor force & 0.27 & & 0.22 & \\
\hline Not in the labor force $0-6$ months & 0.18 & & 0.14 & \\
\hline Not in the labor force 6-12 months & 0.04 & & 0.03 & \\
\hline Not in the labor force $>12$ months & 0.05 & & 0.05 & \\
\hline Temporary employed & 0.15 & & 0.01 & \\
\hline Temporary employed 0-6 months & 0.09 & & 0.00 & \\
\hline Temporary employed 6-12 months & 0.02 & & 0.00 & \\
\hline Temporary employed > 12 months & 0.04 & & 0.00 & \\
\hline Regularly employed & 0.19 & & 0.62 & \\
\hline Employed 0-6 months & 0.08 & & 0.34 & \\
\hline Employed 6-12 months & 0.04 & & 0.05 & \\
\hline Employed $>12$ months & 0.07 & & 0.22 & \\
\hline Job tenure (months) & 12.80 & 15.73 & 37.96 & 22.35 \\
\hline Months employed during past 5 years & 36.28 & 18.28 & 52.88 & 12.86 \\
\hline No previous temp jobs & 0.80 & 2.55 & 0.03 & 1.79 \\
\hline No of all previous jobs & 2.68 & 2.55 & 1.07 & 1.79 \\
\hline \multicolumn{5}{|l|}{ Occupation } \\
\hline Technical occupation & 0.03 & & 0.09 & \\
\hline Manufacturing other & 0.08 & & 0.16 & \\
\hline Manufacturing metal sector & 0.32 & & 0.15 & \\
\hline Laborer & 0.26 & & 0.01 & \\
\hline Clerical occupation & 0.13 & & 0.35 & \\
\hline Service occupation & 0.17 & & 0.21 & \\
\hline \multicolumn{5}{|l|}{ Firm characteristics } \\
\hline Firm size $1-10$ & 0.03 & & 0.17 & \\
\hline Firm size 11-20 & 0.05 & & 0.10 & \\
\hline Firm size $21-50$ & 0.22 & & 0.14 & \\
\hline Firm size 51-200 & 0.53 & & 0.23 & \\
\hline Firm size > 200 & 0.17 & & 0.37 & \\
\hline Age of the firm & 8.96 & 6.91 & 17.27 & 9.51 \\
\hline
\end{tabular}


Figure 1: Average wage gap in percent for temp workers, 1997 - 2004

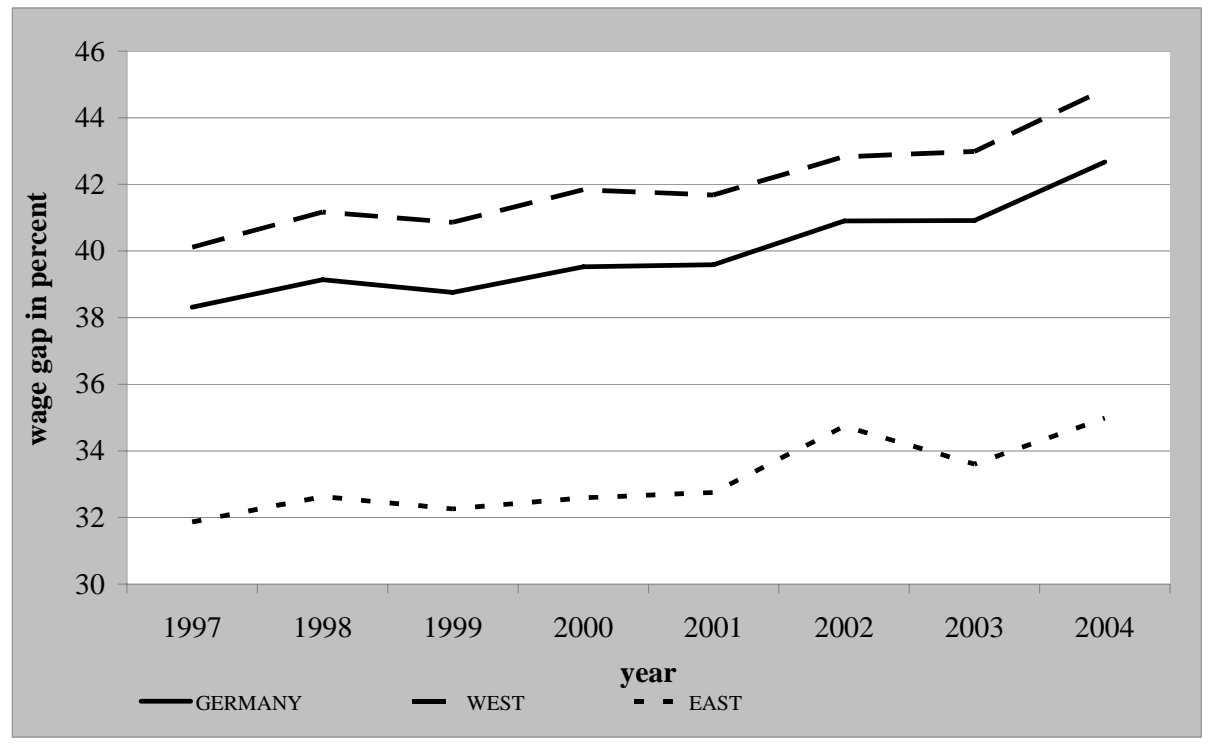

Source: IABS 1997-2004

Table 2: Estimates wage differentials for temp and regular workers in \%, 1997-2004

\begin{tabular}{|c|c|c|c|c|c|c|c|c|c|}
\hline & \multicolumn{3}{|c|}{ Germany } & \multicolumn{3}{|c|}{ West } & \multicolumn{3}{|c|}{ East } \\
\hline & All & Male & Female & All & Male & Female & All & Male & Female \\
\hline (1) Base model & -34.2 & -35.7 & -26.4 & -35.3 & -37.2 & -27.0 & -28.6 & -29.3 & -24.6 \\
\hline SE & $(0.002)$ & $(0.002)$ & $(0.004)$ & $(0.002)$ & $(0.002)$ & $(0.004)$ & $(0.004)$ & $(0.004)$ & $(0.010)$ \\
\hline $\mathrm{R} 2$ & 0.473 & 0.480 & 0.365 & 0.452 & 0.439 & 0.338 & 0.417 & 0.416 & 0.415 \\
\hline (2) Adding occupation & -32.1 & -33.2 & -26.0 & -33.6 & -35.1 & -27.1 & -26.0 & -26.5 & -23.7 \\
\hline SE & $(0.002)$ & $(0.002)$ & $(0.004)$ & $(0.002)$ & $(0.002)$ & $(0.004)$ & $(0.004)$ & $(0.004)$ & $(0.010)$ \\
\hline R2 & 0.495 & 0.510 & 0.383 & 0.473 & 0.471 & 0.350 & 0.449 & 0.449 & 0.456 \\
\hline (3) Adding empl. history & -21.9 & -22.8 & -16.9 & -23.1 & -24.5 & -17.6 & -17.0 & -17.0 & -15.6 \\
\hline $\mathrm{SE}$ & $(0.002)$ & $(0.002)$ & $(0.004)$ & $(0.002)$ & $(0.002)$ & $(0.004)$ & $(0.004)$ & $(0.004)$ & $(0.009)$ \\
\hline $\mathrm{R} 2$ & 0.543 & 0.557 & 0.447 & 0.523 & 0.520 & 0.418 & 0.511 & 0.512 & 0.514 \\
\hline (4) Fixed effects & -20.4 & -20.4 & -20.0 & -21.8 & -22.1 & -20.5 & -16.5 & -16.0 & -17.0 \\
\hline $\mathrm{SE}$ & $(0.001)$ & $(0.002)$ & $(0.003)$ & $(0.002)$ & $(0.002)$ & $(0.003)$ & $(0.003)$ & $(0.003)$ & $(0.006)$ \\
\hline Rho & 0.874 & 0.837 & 0.892 & 0.874 & 0.830 & 0.893 & 0.889 & 0.867 & 0.908 \\
\hline No of spells & $3,124,329$ & $2,029,024$ & $1,095,305$ & $2,483,555$ & $1,657,431$ & 826,124 & 640,774 & 371,593 & 269,181 \\
\hline No. of temp spells & 43,031 & 32,903 & 10,128 & 34,506 & 25,950 & 8,556 & 8,525 & 6,953 & 1,572 \\
\hline No. of workers & 611,369 & 370,927 & 240,442 & 487,566 & 303,587 & 183,979 & 139,003 & 78,359 & 60,644 \\
\hline Avg. spells per worker & 5.10 & 5.5 & 4.6 & 5.1 & 5.5 & 4.5 & 4.6 & 4.7 & 4.4 \\
\hline \multicolumn{10}{|c|}{$\begin{array}{l}\text { Source: IABS, own calculation; robust standard errors are reported; controls of the base model (1): age, age2, six educational variables, } 12 \text { re- } \\
\text { gional variables, growth rate of the BIP, five firm size classes, the share of low qualified workers in the firm; the share of high qualified workers } \\
\text { in the firm and the age of the firm. Model (2) includes the controls of the base model (1) and six occupational dummies. Model (3) includes in } \\
\text { addition to Model (2) the current job duration, job duration squared, the total employment duration in the past five years, the number of temp jobs } \\
\text { and regular jobs during the past five years, previous labor force status and their duration in three classes as described in section 4.2. All coeffi- } \\
\text { cients are significant at the } 1 \text { percent level. }\end{array}$} \\
\hline
\end{tabular}


Table 3: Group-specific wage differential according to socio-demographic characteristics in \%, 1997-2004

\begin{tabular}{l|ccc|ccc|ccc}
\hline \hline & \multicolumn{4}{|c|}{ Age } & \multicolumn{3}{c|}{ Education } & \multicolumn{3}{c}{ Agglomeration } \\
& $<\mathbf{2 0}$ & $\mathbf{2 0 - 5 5}$ & $>\mathbf{5 5}$ & No vt & With vt & Univ. & Metro & Urban & Rural \\
\hline Fixed effects & -17.3 & -20.4 & -16.3 & -19.6 & -20.5 & -20.0 & -21.1 & -20.4 & -16.8 \\
SE & $(0.017)$ & $(0.001)$ & $(0.015)$ & $(0.004)$ & $(0.001)$ & $(0.010)$ & $(0.002)$ & $(0.003)$ & $(0.005)$ \\
Rho & 0.814 & 0.874 & 0.922 & 0.904 & 0.895 & 0.776 & 0.868 & 0.897 & 0.905 \\
& & & & & & & & & \\
No of spells & 41,943 & $3,124,329$ & 216,046 & 281,335 & $2,219,508$ & 23,916 & $1,726,031$ & $1,029,276$ & 369,020 \\
No. of temp spells & 1,967 & 43,031 & 1,188 & 8,079 & 29,015 & 515 & 26,976 & 12,631 & 3,424 \\
No. of workers & 32,107 & 611,369 & 80,840 & 71,849 & 43,139 & 8,564 & 358,593 & 219,472 & 81,367 \\
Avg. spells per worker & 1.3 & 5.1 & 2.7 & 3.9 & 5.1 & 2.8 & 4.8 & 4.7 & 4.5 \\
\hline Source: IABS, own calculations; fixed effects panel specification; full set of controls described in Section 4.1 is included. \\
All coefficients are significant at the 1 percent level. \\
\hline \hline
\end{tabular}

Table 4: Temp wage differential according to occupation and firm size in \%, 1997-2004

\begin{tabular}{|c|c|c|c|c|c|c|c|c|c|}
\hline & \multicolumn{3}{|c|}{ Firm size } & \multicolumn{6}{|c|}{ Occupation } \\
\hline & $<20$ & 21-200 & $>200$ & Techn & Manuf & Metal & Laborer & Clerical & Service \\
\hline Fixed effect & -12.6 & -20.8 & -24.3 & -12.6 & -21.0 & -19.9 & -17.6 & -20.3 & -20.5 \\
\hline SE & $(0.006)$ & $(0.002)$ & $(0.005)$ & $(0.011)$ & $(0.004)$ & $(0.002)$ & $(0.005)$ & $(0.005)$ & $(0.005)$ \\
\hline Rho & 0.905 & 0.892 & 0.866 & 0.811 & 0.913 & 0.894 & 0.922 & 0.900 & 0.881 \\
\hline No of spells & 820,980 & $1,165,847$ & $1,137,501$ & 263,699 & 503,176 & 491,228 & 49,301 & $1,097,273$ & 646,566 \\
\hline No. of temp spells & 3,371 & 32,145 & 7,515 & 1,303 & 3,481 & 13,885 & 11,047 & 5,595 & 7,456 \\
\hline No. of workers & 241,714 & 307,993 & 252,231 & 53,905 & 117,885 & 100,157 & 22,181 & 257,880 & 143,014 \\
\hline Avg. spells per worker & 3.4 & 3.8 & 4.5 & 4.9 & 4.3 & 4.9 & 2.2 & 4.3 & 4.5 \\
\hline
\end{tabular}

Table 5: Pre- and post-earnings in \%, 1997-2002

\begin{tabular}{lccccc}
\hline \hline & All & Germany & & West & East \\
& -2.54 & -2.12 & -3.57 & -1.80 & -3.67 \\
\hline 3 yrs before & $(0.005)^{* * *}$ & $(0.006)^{* * *}$ & $(0.009)^{* * *}$ & $(0.006)^{* * *}$ & $(0.008)^{* * *}$ \\
& -3.35 & -3.44 & -2.85 & -2.32 & -4.67 \\
$\mathbf{2}$ yrs before & $(0.005)^{* * *}$ & $(0.006)^{* * *}$ & $(0.009)^{* * *}$ & $(0.006)^{* * *}$ & $(0.008)^{* * *}$ \\
& -6.88 & -7.27 & -5.56 & -6.65 & -6.86 \\
$\mathbf{1}$ yr before & $(0.005)^{* * *}$ & $(0.005)^{* * *}$ & $(0.008)^{* * *}$ & $(0.005)^{* * *}$ & $(0.008)^{* * *}$ \\
& -22.47 & -22.61 & -21.19 & -23.09 & -20.42 \\
Temp-episode (FE) & $(0.003)^{* * *}$ & $(0.004)^{* * *}$ & $(0.006)^{* * *}$ & $(0.004)^{* * *}$ & $(0.007)^{* * *}$ \\
& -1.76 & -1.07 & -3.05 & -1.29 & -2.94 \\
$\mathbf{1}$ yr after & $(0.004)^{* * *}$ & $(0.005)^{* *}$ & $(0.008)^{* * *}$ & $(0.005)^{* * *}$ & $(0.009)^{* * *}$ \\
& -0.30 & -0.12 & -0.55 & -0.05 & -1.14 \\
$\mathbf{2}$ yrs after & $(0.004)$ & $(0.005)$ & $(0.008)$ & $(0.005)$ & $(0.009)$ \\
& -0.18 & -0.51 & 0.92 & -0.02 & -1.18 \\
$\mathbf{3}$ yrs after & $(0.005)$ & $(0.005)$ & $(0.008)$ & $(0.005)$ & $(0.010)$ \\
& & & & & \\
& -16.74 & -16.54 & 16.56 & -17.61 & -14.56 \\
Wage gap ( $\left.\hat{\beta}_{0}-\hat{\beta}_{-1}\right)$ & & & & & \\
& $2,333,229$ & $1,508,273$ & 824,956 & $1,845,265$ & 487,964 \\
No of spells & 20,777 & 15,458 & 5,319 & 16,771 & 4,006 \\
No. of temp spells & 559,782 & 341,357 & 218,425 & 443,153 & 127,429 \\
No. of workers & 4.20 & 4.4 & 3.8 & 4.2 & 3.8 \\
Avg. spells per worker & 4 & & & & \\
\hline Source: IABS. own calculations; standard errors in parenthesis, ***,** denotes significance at the 1,5 \\
percent level.
\end{tabular}


Table 6: The effect of the 2003 reform on the wage gap in \%

\begin{tabular}{llccc}
\hline \hline & & All & Male & Female \\
\hline Germany & Reform & -2.45 & -2.49 & -2.33 \\
& & $(0.000)$ & $(0.000)$ & $(0.000)$ \\
& Reform*TAW & -4.85 & -5.60 & -2.39 \\
\multirow{2}{*}{ West } & \multirow{2}{*}{ Reform } & -2.52 & $(0.002)$ & $(0.002)$ \\
& & -2.61 & -2.30 \\
& Reform*TAW & -5.65 & $(0.000)$ & $(0.000)$ \\
& & $(0.002)$ & -6.45 & -3.22 \\
East & Reform & -1.96 & -1.68 & $-2.002)$ \\
& & $(0.000)$ & $(0.000)$ & $(0.000)$ \\
& Reform*TAW & -1.91 & -2.80 & 2.94 \\
& & $(0.002)$ & $(0.002)$ & $(0.002)$ \\
\hline Source: IABS. own calculations; standard errors in parenthesis, all coefficients are signifi- \\
cant at the 1 percent level
\end{tabular}

